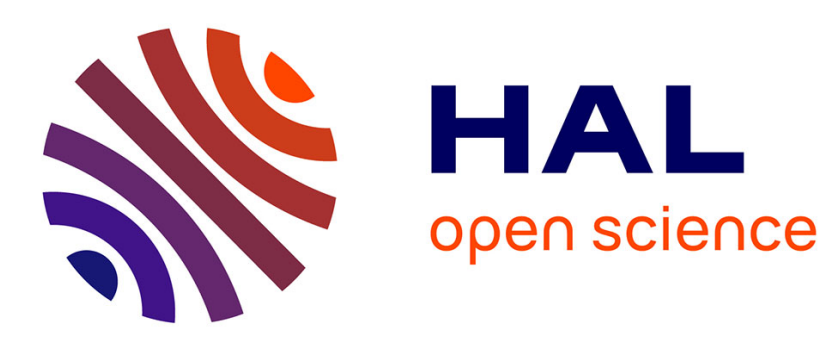

\title{
Synthesis of $(\mathrm{R}, \mathrm{R})$ and $(\mathrm{S}, \mathrm{S})$ \\ bicyclo[3.3.0]octane-2,6-dione interactions between non-conjugated chromophores
}

Joelle Pérard-Viret, André Rassat

\section{- To cite this version:}

Joelle Pérard-Viret, André Rassat. Synthesis of (R,R) and (S,S) bicyclo[3.3.0]octane-2,6-dione interactions between non-conjugated chromophores. Tetrahedron: Asymmetry, 1994, 5 (1), pp.1-4. 10.1016/S0957-4166(00)80469-3 . hal-03376775

\section{HAL Id: hal-03376775 \\ https://hal.science/hal-03376775}

Submitted on 13 Oct 2021

HAL is a multi-disciplinary open access archive for the deposit and dissemination of scientific research documents, whether they are published or not. The documents may come from teaching and research institutions in France or abroad, or from public or private research centers.
L'archive ouverte pluridisciplinaire HAL, est destinée au dépôt et à la diffusion de documents scientifiques de niveau recherche, publiés ou non, émanant des établissements d'enseignement et de recherche français ou étrangers, des laboratoires publics ou privés. 


\title{
Synthesis of (R,R) and (S,S) Bicyclo[3.3.0]octane-2,6-dione Interactions Between Non-Conjugated Chromophores
}

\author{
Joëlle Pếrard-Viret, André Rassat* . \\ URA CNRS 1679, Ecole Normale Superieure. Département de chimie \\ 24 ne Lhomond 75231 Paris Cedex 05, France.
}

\begin{abstract}
Optically pute bicyclo(3.3.0joctane-2, 6-dione is easily obtained with a yield of $4 \%$ for each enantiomer from 1,5 -oyclooctadiene in 5 steps, by resolution of the intermediate diol with menthyloxyacetic acid. Its CD is 60 \% larger than twice the $\mathrm{CD}$ of a correspondiag monoketone indicating interactions berween non-conjugated chromophores.
\end{abstract}

Interactions between non conjugated chromophores have been characterized in bicyclo[3.3.0]octane-2,6-dione 1 by ${ }^{13} \mathrm{C}$ nuclear magnetic resonance (NMR)! Similar interactions have also been observed by chiroptical methods, optical rotatory dispersion (ORD) ${ }^{2}$ and circular dichroism $(C D)^{3}$, when the Cotton effect ( $\triangle \varepsilon$ in $C D$ or amplitude a in ORD) is larger than the sum of the Cotton effects of the corresponding monoketonic moeities ${ }^{2}$, the UV spectrum being only weakly perturbed. Since diketone 1 has $C_{2}$ symmetry, it may be expected that the previously reportod interactions could also be observed by chiroptical methods.

Optically active dikctone 1 and monoketonic derivatives 2 have been prepared ${ }^{4-6}$ in various degres of optical purily and their absolute configuration established by chenical correlation ${ }^{7} \mathrm{NMR}^{6}$ and $\mathrm{CD}^{5}$,
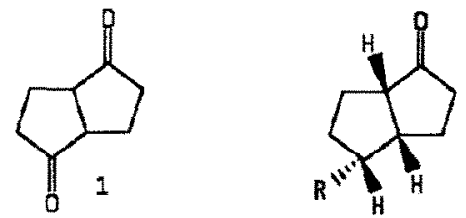

2a $R=H$

2b $\mathrm{R}=\mathrm{OH}$

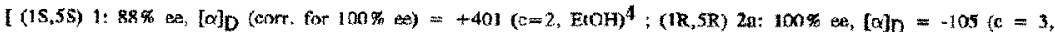

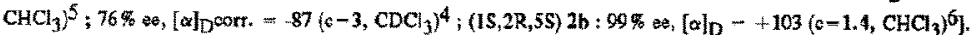

Their ORD data have been published ${ }^{3.4}$. As shown in figure 1 , the ORD of diketone $1(\mathrm{IS}, 5 S)^{4}$ (corrected for $100 \%$ optical purity) is larget than twice the ORD of monoketone 2 a (1R,SR) (optically pure or corrected to $100 \%$ optical purity). Unfortunately, this data does not permit the determination of the corresponding amplitude a.

Figure 1 : Optical rotatory dispersion of

1 (EtOH) :0 $-0 \rightarrow 0$ (ref. 3)

2a $\left(\mathrm{CDCl}_{3}\right): \bullet-\bullet$ (ref. 3$)$

2a $\left(\mathrm{CHCl}_{3}\right): \Delta-\Delta-\Delta$ (ref. 4)

(corrected for $100 \%$ optical purity)

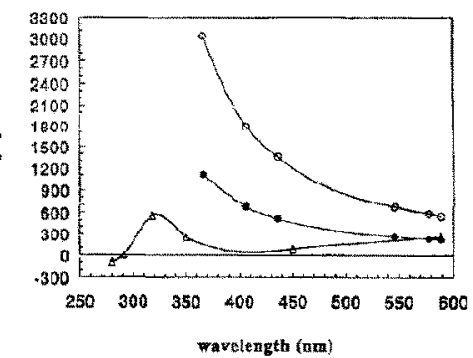


Since enantiomerically pure diketone 1 could be a useful synthon $8-11$, we thought it would be worthwhile to develop an expedient chemical way to obtain both enantiomers. This could allow us to measure its $C D$ and compare it to the CD of monokelonic derivatives. A combination of several reported procedures was choosen $10,12,13$ (alternatively 1 is accessible via an other synthesis ${ }^{14}$ ) :

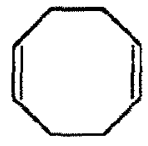

3

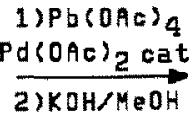

2) $\mathrm{KOH} / \mathrm{MeOH}$<smiles>C[C@H]1CC[C@H]2[C@@H](O)CC[C@H]1[C@H]2O</smiles>

OR 4a $R=A c, 4 b \quad R=H$

Thus, 1,5 -cyclooctadiene $3(6.6 \mathrm{~g})$ was ureated for 36 hours with catalytic amounts of $\mathrm{Pd}(\mathrm{OAc})_{2}$ (400mg, $0.02 \mathrm{eq})$ in the presence of $1 \mathrm{M} \mathrm{Pb}(\mathrm{OAc})_{4}(39 \mathrm{~g})$ in acetic acid at room temperature. The main product was the diendo diastereoisomer $4 \mathrm{a}\left(8.5 \mathrm{~g} 63 \%\right.$, colourless crystals, from pentane, $\mathrm{mp} 40^{\circ} \mathrm{C}$, lit ${ }^{9}$ $36^{\circ} \mathrm{C}$ ). Saponification of $4 \mathrm{a}\left(1.43 \mathrm{~g}\right.$ in $5 \mathrm{ml}$ of $\mathrm{MeOH}$ ) (KOH:MeOH $1.33 \mathrm{M}(4 \mathrm{ml}), 45 \mathrm{~min} 0^{\circ} \mathrm{C}$, then $30 \mathrm{~min} 20^{\circ} \mathrm{C}$ ) gave $0.8 \mathrm{~g}$ of the diendo diol $4 \mathrm{~b}(00 \% \text {, colourless oil })^{11}, 0.85 \mathrm{~g}$ oxidized to dinne $1(0.6 \mathrm{~g}$ : $70 \%$ ) (Jones reagent $(2.7 \mathrm{M})$, acetone $\left.(20 \mathrm{ml}), 1 \mathrm{~h} 0^{\circ} \mathrm{C}, 15 \mathrm{~h} \mathrm{rt}\right)\left(\mathrm{mp} 45^{\circ} \mathrm{C}, 1 \mathrm{tit} 45-46^{\circ} \mathrm{C}\right)$. The use of palladium acetate suppresses the formation of 6-exo-chloro-2-endo-acetoxy[3.3.0] octane, a by-product of the palladium chloride catalysed reaction ${ }^{15}$.

Attempts to resolve directly the dione by inclusion in $\beta$-cyclodextrin, in 1,6-bis(2-chloropheny1)-1,6-diphenyl-2,4-hexadiyne-1,6-diol, or via covalent derivatives with dimethyl tartrate or (S)-1-amino-2-(methoxymethyl)pyrrolidine (SAMP) failed. The resolution was done on diol $\mathbf{4 b}$. Esterification of $4 \mathrm{~b}(1.7 \mathrm{~g})$ with $(-)$ menthyloxyacetic acid $(5.5 \mathrm{~g})$ (DCC $(5.8 \mathrm{~g}) / \mathrm{DMAP}(0.3 \mathrm{~g})$, diethyl ether, $2 \mathrm{~h} 0^{\circ} \mathrm{C}$, $15 \mathrm{~h} \mathrm{rt}$ ) (scheme 1) gave a mixture of the two diastereoisomers $5 \mathrm{~A}$ and $5 \mathrm{~B}$ (5g, 78\%, after chromatography on $\mathrm{SiO}_{2}$, pentane/ether $(8: 2)$. After two recrystallisations in pentane, an optically pure product ${ }^{16} \mathbf{5 A}(15 \%)$ was obtained. Its optical purity $(99 \%)$ was confirmed by differential scanning calorimctry (DSC) ${ }^{17}$. Saponification of $5 \mathrm{~A}(0.35 \mathrm{~g}$ in $2 \mathrm{ml} \mathrm{MCOH})(\mathrm{KOH} / \mathrm{McOH}(0.34 \mathrm{M}, 3 \mathrm{ml}), 90 \%)$, gives $(1 \mathrm{~S}, 2 \mathrm{R}, 5 \mathrm{~S}, 6 \mathrm{R})$ ab $(85 \mathrm{mg}),[\alpha]_{\mathrm{D}}=-39\left(\mathrm{c}=0.5, \mathrm{CHCl}_{3}\right), \mathrm{lit} t^{4}:[\alpha]_{\mathrm{D}}=-48\left(\mathrm{c}=2, \mathrm{CHCl}_{3}\right)$; vapor phase chromatography of its corresponding o-acetylactyldiester ${ }^{18}$ shows an enantiomeric excess greater than $99 \%$, 4b was oxidized as previously to afford the dione (15,5S) 1 (50-70\%, colourless needles, $\mathrm{mp}$ $43^{\circ} \mathrm{C} ;[\alpha]_{\mathrm{D}}=+394(\mathrm{c}=0.25, \mathrm{EtOH}),[\alpha]_{\mathrm{D}}=+474\left(\mathrm{c}=0.05, \mathrm{CH}_{2} \mathrm{Cl}_{2}\right), \mathrm{lit}^{4}[\alpha]_{\mathrm{D}}=+401 \quad(\mathrm{c}=2$, EtOH)). (+) Menthyloxyacetic acid gave the dione $(\mathrm{IR}, 5 \mathrm{R}) \mathrm{1},[\alpha]_{\mathrm{D}}=-457\left(\mathrm{c}=1, \mathrm{CH}_{2} \mathrm{Cl}_{2}\right)$.

Scheme 1

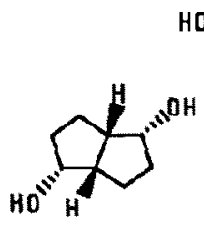

$4 \mathrm{~b}$

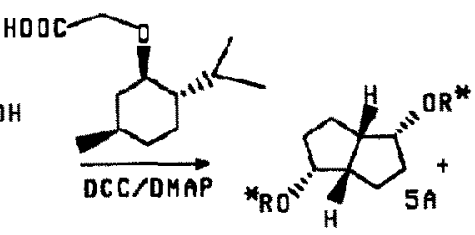

$R=$ Menthyloxyacetyl

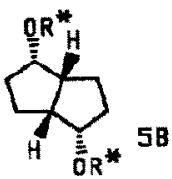

$5 \mathrm{~B}$

Monoketonealcohol $2 \mathrm{~b}$ (enulo-2-hydroxy-6-oxobicyclo[3.3.0]octane) was prepared by enzymatic reduction ${ }^{19}$ ( 7 days, $\mathrm{rt}$ ) with horse liver alcool deshydrogenase (HLADH) (12mg, 2U/mg) of 1 (40mg), $11 \mathrm{mg}$ were obtained $\left(30 \%\right.$, colourless oil ${ }^{20},[\alpha]_{\mathrm{D}}=+113\left(\mathrm{c}=0.35, \mathrm{CHCl}_{3}\right)$, lit $\mathrm{t}^{6}$ for $(1 \mathrm{~S}, 2 \mathrm{R}, 5 \mathrm{~S}) 2 \mathrm{~b}$ : 
$[\alpha]_{\mathrm{D}}=+103\left(\mathrm{c}=1.38, \mathrm{CHCl}_{3}\right)$ ). It has a $\Delta \varepsilon=1.4 \mathrm{M}^{-1} \mathrm{~cm}^{-1}$ in $\mathrm{CH}_{2} \mathrm{Cl}_{2}$. Figure 2 shows the octant diagram of (IS,2R,SS) $2 \mathrm{~b}$ obtained after energy minimization ${ }^{21}$ : this leads to a positive Cotton effect in full agreement with experiments.

Figure 2:

Octant diagram of $\mathbf{2 b}$

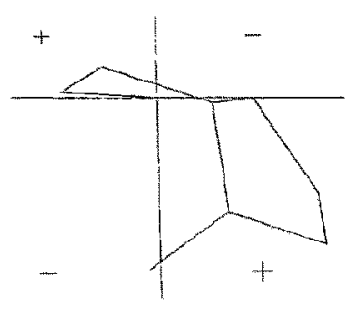

We are now in a position to compare the circular dichroism of diketone 1 and its monoketonic derivative $2 \mathrm{~b}$. The UV absorption of 1 (fig. 3) shows a hypsochromic shift relative to $2 \mathrm{~b}$ from $302 \mathrm{~nm}$ to $292 \mathrm{~nm}\left(\Delta v=1134 \mathrm{~cm}^{-1}\right), \varepsilon$ of the diketone 1 being almost exactly twice that of the monoketone 2b. Its $\mathrm{CD}$ is much larger than twice the $\mathrm{CD}$ of $\mathbf{2 b}$ (fig. 4). Without any interaction between

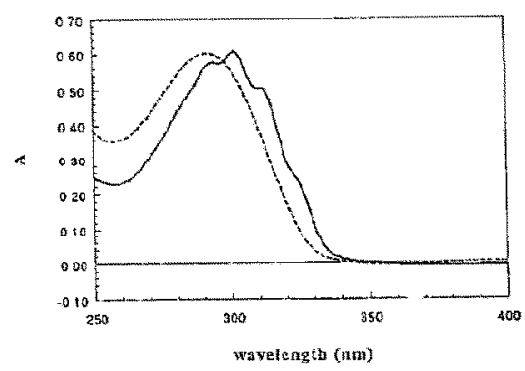

Figure $3:$ UV spectrum of $2 \mathbf{b}$ : and of $1:-$ in $\mathrm{CH}_{2} \mathrm{Cl}_{2}$, (molar concentration of $2 \mathrm{~b}$ is twice that of 1 ) $(\varepsilon$ of $1=46 ; \varepsilon$ of $2 b=23)$

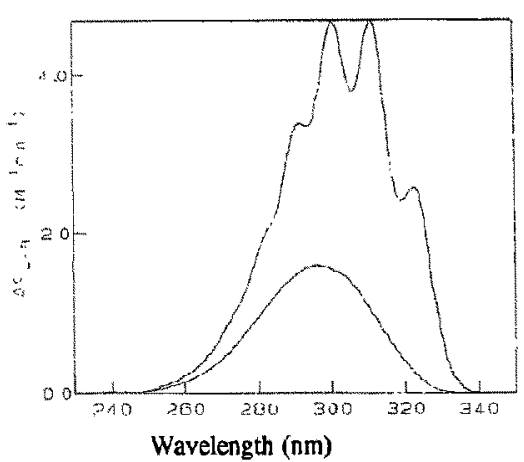

Figure 4 : Circular Dichroism of monoketone $2 \mathrm{~b}$, diketone 1 in $\mathrm{CH}_{2} \mathrm{Cl}_{2}$

chromophores, we could expect a $\Delta \varepsilon$ of $2.8 \mathrm{M}^{-1} \mathrm{~cm}^{-1}$ for $(\mathrm{IS}, 5 \mathrm{~S}) \mathrm{I}$ in $\mathrm{CH}_{2} \mathrm{Cl}_{2}$. The measured value $\left(\Delta \varepsilon=4.671 \mathrm{M}^{-1} \mathrm{~cm}^{-1}\right.$ ) is larger by $60 \%$. This large increase can be taken as a manifestation in the $\mathrm{CD}$ of the effect previously detected in 1 by ${ }^{13} \mathrm{C} \mathrm{NMR}^{1}$. The $1134 \mathrm{~cm}^{-1}$ shift in the UV absorption may be taken as the order of magnitude of the splitings of the $n$ and $\pi^{*}$ levels ${ }^{22}$ in diketone 1 . It is probable that a quantitative treatment of these interactions should also lake into account the $C_{2}$ symmetry of 1 .

Acknowlegments : We thank Liliane Leroy (Univ. PARIS 6) for circular dichroism measurements, and Claudine Fouquey (Collège de France) for DSC measurements. 


\section{References and notes}

1. T. Doerner, R. Gleiter, T.A. Robbins, P. Chayangkoon, D.A. Lightner, J. Am. Chem. Soc., 1992, 114, 3235. In fact the NMR effect is much larger than reported : instead of $\Delta \delta=-0.6$ reported between the $\mathrm{C}_{2} / \mathrm{C}_{6}$ chemical shifts, we found $\Delta \delta=-2.9$, as in J.K. Whitesell, K.S. Matthews, J. Org. Chem, $1977,42,3878$.

2. C. Djerassi, "Optical Roratory Dispersion", Mc Graw-Hill, 1960, p71.

3. T.A. Robbins, V.V. Toan, J.W. Givens, III, D.A. Lightner, J. Am. Chem. Soc, 1992, 114, 10799.

4. M.A. Djadchenko, V.I. Mel'nikova, K.K. Pivnitsky, Zh. Obshch. Khim., 1986, 56, 2143.

5. J.K. Whitesell, M.A. Minton, S.W. Felman, J. Org. Chem., 1983, 48, 2193.

6. Z.F. Xie, H. Suemune, K. Sakai, Tetrahedron Asymmerry, 1990, 1,395.

7. H. Kuritani, Y. Takaska, K. Shingu, J. Org. Chem., 1979, 44, 452.

8. A.A Hagedorn III, D.G. Farnum, J. Org. Chem, 1977, 42, 3765; S. Wawzonek, J. Am. Chem. Soc, 1943, 65, 839; C.T. Blood, R.P. Linstead, J. Chem. Soc, 1952, 2255; D.G. Farnum, A.A. Hagedorn III, Tetrahedron Lert., 1975, 3987; Y Tobe, K. Terashima, Y. Sakai, Y Odaira, J. Am. Chem. Soc., 1981, 103, 230715; M. Tanaka, H. Suemune, K. Sakai, Tetrahedron lett., 29, 1988, 1733.

9. M.A. Mc Kervey, P. Vibuljan, G. Ferguson, P.Y. Siew, J.C.S. Chem. Comm., 1981, 912.

10. K. Yu. Chernyuk, V.I. Mel'nikova, K.K. Pionitsky, Zh. Org. khim, 1982, 18, 577.

11. M.A. Djadchenko, K. K. Pivnitsky, F. Theil, H. Schick, J. Chem. Soc Perkin Trans I, 1989, 2001.

12. R.N. Moriarty, M.P. Duncan, R.K. Vaid, O. Prakash, Org. Symh., 1990, 68, 175.

13. P.M. Henry, M. Davies, G. Ferguson, S. Phillips, R. Restivo, J.C.S. Chem. Comm., 1974, 112.

14. L. Ruzicka, A. Borges de Almcida, A. Brack, Helv. Chim. Acta, 1934, 17, 183; H. Quast, R. Janiah, Liebigy Arn. Chern., 1991, 1305, T.S. Cantrell, B.I. Strasser, J. Org. Chem., 1971, 36, 670; M. Julia, E. Colomer, An. Quim., 1971, 67, 199; P.H. Mc Cabe, C.R. Nelson, Tetrahedron Lett., 1978, 2819; J.K. Crandall, C.F. Mayer, J. Am. Chem. Soc., 1967, 89, 4374.

15. S.K. Chung, A.I. Scott, Tetrahedron Letr., $1975,49$.

16. ${ }^{1} \mathrm{H} \mathrm{NMR}\left(\mathrm{CDCl}_{3}, 250 \mathrm{MHz}, \mathrm{d} \mathrm{ppm}\right): 0.8(\mathrm{~m}, \mathrm{~d}, \mathrm{~J}=7 \mathrm{~Hz} ; 8 \mathrm{H}), 0.9(\mathrm{~m}, \mathrm{dd}, 16 \mathrm{H}), 1.3(\mathrm{~m}, 4 \mathrm{H}), 1.6$ $(\mathrm{m}, 8 \mathrm{H}), 1.75(\mathrm{~m}, 4 \mathrm{H}), 2.05(\mathrm{~m}, 2 \mathrm{H}), 2.3(\mathrm{~m}, 2 \mathrm{H}), 2.75(\mathrm{~m}, 2 \mathrm{H}), 3.15(\mathrm{~m}, 2 \mathrm{H}), 4.1(\mathrm{dd} A B \mathrm{~J}=16 \mathrm{~Hz})$. $5.18(\mathrm{~m}, 2 \mathrm{H}) ;{ }^{13} \mathrm{C} \mathrm{NMR}\left(\mathrm{CDCl}_{3}, 62.9 \mathrm{MHz}, \mathrm{d} \mathrm{ppm}\right): 16.22(\mathrm{q}), 20.09$ (q), 22.2 (q), 22.7 (t), 23.2 (t), 25.4 (d), 31.4 (d), 32.1 (t), 34.3 (t), 39.9 (t), 44.6 (d), 48 (d), 66 (t), 77.4 (d), 80.2 (d), 170.4 (s); $\mathbf{F}=84.24^{\circ} \mathrm{C}(\mathrm{DSC}) ;[\alpha]_{\mathrm{D}}=-129.7\left(\mathrm{c}=0.15, \mathrm{CH}_{2} \mathrm{Cl}_{2}\right)$

17. J. Jacques, A. Collet, S.H. Wilen, "Enantiomers, Racemates and Resolutions", J. Wiley \& Sons, New York, 1981, p151.

18. A. Mosandl, M. Gessner, C. Günther, W. Deger, G. Singer, J. High Resalur. Chromatogr. Chromatogr. Commun., 1987, 10, 67.

19. D.R. Dodds, J.B. Jones, J. Am. Chem. Soc., 1988, 110, 577.

20. ${ }^{13} \mathrm{C}$ NMR $\left(\mathrm{CDCl}_{3}, 62.9 \mathrm{MHz}, \mathrm{d} \mathrm{ppm}\right): 20.05(\mathrm{t}), 25.15(\mathrm{t}), 35.09(\mathrm{t}), 38.40$ (t), 45.73 (d), 50.44 (d), 75.64 (d), 223.69 (s)

21. Quanta 3.3, Silicon Graphics IRIS workstation, Charm, minimization method : Adopted-Basis Newion Raphson.

22. H.D. Martin, B. Mayer, Angew. Chem. Int. Ed. Engl., 1983, 22, 283. 